\title{
Transhumanizm: kilka uwag na temat filozoficznych źródeł sporu o ideę biomedycznego ulepszania moralnego ${ }^{1}$
}

Marta Soniewicka (Uniwersytet Jagielloński, Kraków)

\section{Wprowadzenie}

Termin „transhumanizm” został stworzony przez angielskiego biologa Juliana Huxleya, starszego brata słynnego pisarza Aldousa Huxleya. Biolog zatytułował nim opublikowany w 1957 roku esej, w którym ogłosił pojawienie się nowej „kosmicznej samoświadomości”, która pozwoli ludzkości wziąć odpowiedzialność za ewolucję i zdecydować o przyszłości ludzkości (Huxley 1968, 73). Człowiek został mianowany „dyrektorem zarządzającym największego przedsiębiorstwa ze wszystkich-ewolucji", jak pisze, a choć wcale się o to stanowisko nie prosił, nie może z niego zrezygnować (Huxley 1968, 73). „Kosmicznym obowiązkiem” ludzkości jest to, by w pełni rozwinąć ludzkie możliwości, czy to indywidualnej jednostki, czy wspólnoty, czy wreszcie gatunku, działając na rzecz dobrobytu przyszłych pokoleń i postępu ludzkości (Huxley 1768, 76). Pierwszym zadaniem w realizacji tego celu, koniecznym, by zbadać zakres ludzkich możliwości, jest odkrycie ludzkiej natury, gdzie „przeogromny Nowy Świat nieznanych możliwości czeka na swoich Kolumbów" (Huxley 1968, 74). Apel Huxleya, by stworzyć wewnętrzną mapę ludzkich możliwości nie musiał długo czekać na odpowiedź. Sekwencjonowanie całego genomu ludzkiego udało się naukowcom osiągnąć pięćdziesiąt lat później, a niektórzy politycy, jak prezydent Bill Clinton czy premier Tony Blair, okrzyknęli to odkrycie najważniejszą mapą ludzkości i instrukcją obsługi człowieka (Collins 2006, 2-3). Czytając tekst angielskiego biologa nasuwa się pytanie, czy to odkrycie utoruje drogę do głoszonego przez niego transhumanizmu:

Gatunek ludzki może, jeśli tego sobie życzy, przekroczyć siebie nie tylko sporadycznie, przez jakąś jednostkę tu czy tam, w ten czy inny sposób, ale w całości, jako ludzkość. Potrzebujemy nazwy dla tej nowej wiary. Być może transhumanizm będzie tu odpowiedni: człowiek pozostanie człowiekiem, ale

\footnotetext{
${ }^{1}$ Projekt został sfinansowany ze środków Narodowego Centrum Nauki przyznanych na podstawie decyzji numer DEC-2012/07/D/HS1/01099.

Specjalne podziękowania należą się Recenzentowi/Recenzentce tego artykułu, gdyż wnikliwe uwagi do pierwszej wersji tekstu wpłynęły na jego ostateczny kształt.
} 
przekraczającym samego siebie poprzez realizowanie nowych możliwości ludzkiej natury i dla ludzkiej natury (Huxley 1968, 76).

Z pewnością ta wiara, określana przez autora eseju także mianem „ewolucyjnego humanizmu” (Bashford 2013, 160-161), znalazła swych wyznawców na gruncie współczesnej bioetyki. Jeden z nich, John Harris, wyraził swój entuzjazm wobec udoskonalania ewolucji w słowach:

Doniosłym jest, że osiągnęliśmy punkt w rozwoju ludzkiej historii, w którym dalsze próby, by uczynić świat lepszym miejscem będą musiały obejmować nie tylko zmiany świata, ale również zmiany ludzkości, w konsekwencji czego być może my bądź nasi potomkowie przestaniemy być ludźmi w znaczeniu, w którym teraz rozumiemy to pojęcie. ... Ten nowy proces ewolucyjnej zmiany zastąpi selekcję naturalnq selekcja umyślnq, ewolucję darwinowskq „ewolucjq udoskonalania” (Harris 2007, 4).

Transhumanizm można zdefiniować jako ruch zwolenników wykorzystania dostępnych technik, w tym neuro-, bio- i nano-technologii, w celu ulepszenia gatunku ludzkiego (Birnbacher 2008, 95). Formę ludzkiej egzystencji, będącą wynikiem zastosowania owej radykalnej transformacji technologicznej określa się mianem „posthumanizmu”, którego orędownikami są transhumaniści tacy, jak: Nick Bostrom, Nicholas Agar, Ingmar Persson, Julian Savulescu (Bostrom 2008, Agar 2008, Persson, \& Savulescu 2012)2. Posthumanizm ma polegać na przekroczeniu ograniczeń wbudowanych w ludzką kondycję, jaka jest nam obecnie znana. Przez „postludzi” Bostrom rozumie osobniki, które posiadają przynajmniej jedną „postludzką” zdolność czyli zdolność przekraczającą normalne zdolności gatunkowe człowieka, dotyczącą kondycji zdrowotnej (np. długość życia powyżej 100 lat), poznawczej (np. ponadprzeciętny iloraz inteligencji), bądź emocjonalnej (np. ponadprzeciętna empatia) (Bostrom 2008, 108). Tradycyjni przeciwnicy posthumanizmu, określani mianem biokonserwatystów, do których zalicza się między innymi Leona Kassa, Jürgena Habermasa, Franacisa Fukuyamę (Habermas 2003, Fukuyama 2014, Kass 1997)33, widzą w interwencjach biotechnologicznych, mających na celu ulepszenie natury człowieka więcej zagrożeń niż obietnic. Biokonserwatyści, wychodząc $\mathrm{z}$ różnych założeń, przykładają wartość do ochrony i zachowania tego, co naturalne. Transhumaniści zaś kwestionują wartościowość tego, co naturalne, wskazując, iż stanowisko biokonserwatystów nie da się utrzymać, gdyż nie wszystko, co naturalne uznawane jest za dobre i warte zachowania, czego najlepszym przykładem są choroby czy wady genetyczne (zob. Kamm 2013, 334).

\footnotetext{
2 Wśród transhumanistów nie ma jednomyślności w odniesieniu do celów i granic ulepszania ludzkiej natury.

${ }^{3}$ Ich argumenty wywodzą się z różnych tradycji filozoficznych.
} 
Spór między transhumanistami a biokonserwatystami może dziś wydawać się nieco przebrzmiały, jednakże istota tego sporu i jego przyczyny są wciąż aktualne $\mathrm{w}$ debacie filozoficzno-bioetycznej i zasługują na uwagę. W niniejszym artykule postaram się wskazać, że spór wokół ulepszania natury człowieka jest rezultatem odmiennych założeń dotyczących tego, jak rozumiemy, czym i kim „człowiek” jest oraz na czym polega ludzki rozwój. By uwypuklić problem nieporozumienia dotyczącego doskonalenia natury człowieka między dwoma wyżej wspomnianymi obozami, zawężę swoje rozważania do najbardziej kontrowersyjnego postulatu transhumanistów do idei moralnego ulepszania człowieka (Kamm 2013, 334). Ulepszanie moralne jest przez transhumanistów rozumiane najczęściej jako zwiększanie zdolności kognitywnych człowieka, które wiążą się $\mathrm{z}$ dyspozycjami do zachowań moralnych, jak również jako odpowiednie uwarunkowanie emocjonalne, które ma na celu stworzenie usposobienia podatnego na zachowanie kooperacyjne (Savulescu, Sandberg, \& Kahane 2011, 56; Douglas 2008, 228-245; Walker 2009, 24-47)4. Jak piszą Persson i Savulescu:

Być moralnie ulepszonym to mieć te skłonności, które sprawiają, że jest bardziej prawdopodobne, że dojdziesz do właściwego sądu dotyczącego tego, jakie działanie jest słuszne oraz że będziesz działał zgodnie z tym sądem (Persson \& Savulescu 2012b, 5).

\section{Odwieczne pragnienie doskonałości}

W słynnym fragmencie Mowy o godności człowieka Pico della Mirandoli czytamy dialog Stwórcy ze Stworzeniem:

Stworzyłem cię jako istotę, która nie jest ani wyłącznie niebiańską, ani ziemską, ani całkowicie śmiertelną, ani nieśmiertelną, byś sam się swobodnie mógł kształtować i przezwyciężać; możesz się wyrodzić i stać się zwierzęciem, i znów się możesz odrodzić jako istota podobna Bogu. Zwierzęta $\mathrm{z}$ łona matki przynoszą na świat wszystko, czego im potrzeba, duchy wyższe od razu lub bardzo rychło stają się tym, czym mają pozostać na całą wieczność. Ty jeden tylko masz swobodę rozwoju, możność potęgowania swych wartości, masz w sobie zarodki pełnego życia (cyt. za: Burckhardt 1991, 218).

Wydawać się może, że głoszona w tym manifeście renesansowego humanizmu nieokreśloność natury ludzkiej, nieograniczona wolność człowieka w jej kształtowaniu oraz imperatyw przekraczania siebie są zgodne $\mathrm{z}$ ideą transhumanistów. Podkreślają oni, że dążenie do doskonałości jest jedną

4 Więcej na ten temat patrz: Soniewicka 2015; także Warmbier 2015. Warto tu wspomnieć, że nie ma między transhumanistami zgody odnośnie do tego, czy istnieją zdolności swoiste związane z moralnością, czy też mamy tu do czynienia z ogólnymi zdolnościami poznawczymi, wykształconymi przez ewolucję i połączonymi z treningiem społecznym (por. Piłat 2013, 169-188). 
z wyróżniających cech gatunku ludzkiego, a teoria ewolucji jest do tego celu najlepszą meta-narracją (Bashford 2013, 161). Jednakże zakorzeniona w filozofii starożytnej oraz tradycji judeochrześcijańskiej idea godności człowieka, do której nawiązuje tekst Pico della Mirandoli, dotyczy etycznej transformacji, pogłębionej refleksji i dążenia do doskonałości w oparciu o założenie działania moralnego, którego warunkiem koniecznym jest wolność. Idea transhumanizmu w kontekście ulepszania moralnego opiera się na odmiennych założeniach i postulatach, co postaram się przybliżyć w dalszych rozważaniach.

Zdaniem transhumanistów, promowanie cnót moralnych może odbywać się zarówno za pomocą tradycyjnych metod wychowawczych, jak i interwencji biomedycznych - oba rodzaje środków służą do osiągnięcia tego samego celu, a różnica pomiędzy nimi polega na ich skuteczności (genetyczne udoskonalanie miałoby być bardziej efektywnym środkiem) (Walker 2009, 35). Tacy filozofowie jak Michael Sandel zarzucają idei udoskonalania człowieka pychę (hybris), która może prowadzić do zguby, gdyż nie zgadzają się z tym, że biomedyczne udoskonalanie może być w ogóle porównywane do tradycyjnych metod wychowawczych (Sandel 2014, 48)5. W dalszej części artykułu postaram się tę argumentację przeciwko idei ulepszania przybliżyć.

\subsection{Kultura (wychowanie) a natura (udoskonalanie)}

Rozważając problematyczność ulepszania natury człowieka, warto przyjrzeć się słynnemu eksperymentowi psychologicznemu, tzw. Marshmallow Test, przeprowadzonemu po raz pierwszy przez Waltera Mischela na Uniwersytecie Stanforda $w$ latach sześćdziesiątych i siedemdziesiątych dwudziestego wieku (Mischel, Shoda, \& Rodriguez 1989, 933-938). W eksperymencie brały udział dzieci w wieku przedszkolnym (cztero- i pięciolatki), którym proponowano wybór pomiędzy natychmiastową gratyfikacją w postaci jednej słodkiej pianki (marshmallow) albo większą gratyfikacją $\mathrm{W}$ postaci dwóch słodkich pianek, odłożoną $\mathrm{w}$ czasie (tj. po upływie kilkunastu minut, co tak małym dzieciom wydaje się wiecznością). Niektóre dzieci nie były w stanie poczekać na podwójną nagrodę i konsumowały piankę natychmiast; niektóre, pozostawione sam na sam z pianką niecierpliwie czekały na powrót eksperymentatora, ale udawało im się wytrwać; jeszcze inne realizowały zadanie jedynie częściowo, nadgryzając pozostawioną im piankę i licząc mimo wszystko na podwójną nagrodę. Najbardziej interesującym aspektem tych badań było to, że organizatorzy eksperymentu śledzili dalsze losy życiowe dzieci i ich rozwój, analizując korelację między zdolnością do samokontroli a sukcesem życiowym. Z tych wieloletnich badań wyprowadzono wnioski, że dzieci, które we wczesnym stadium dzieciństwa okazywały umiejętność odkładania

${ }_{5}$ Znamiennym jest, że tytuł książki Michaela Sandela brzmi w oryginale The Case Against Perfection. Na temat tej książki patrz: Drwięga $(2008,80-91)$. 
gratyfikacji w czasie, okazywały się bardziej inteligentne i skoncentrowane, miały mniejsze skłonności do tycia, lepiej radziły sobie ze stresem i frustracją, a co za tym idzie odnosiły większe sukcesy w nauce i karierze zawodowej, a także miały więcej powodzenia w życiu rodzinnym i osobistym (Shoda, Mischel, \& Peake 1990, 986-987). Fakt, iż już u czterolatków występowały tak znaczące różnice w strategiach działania, wyjaśniano cechami wrodzonymi, a nie nabytymi dzieci, co przechylało szalę na rzecz większej roli genów niż wychowania w rozwoju człowieka.

Podobne wnioski wyprowadzano z badań przeprowadzanych przez Hamman i Tomasello w Instytucie Antropologii Ewolucyjnej Maxa Plancka w Lipsku-badane czterolatki miały wykazywać wrodzone predyspozycje do współpracy i poczucia sprawiedliwości (Hamman, Warneken, Greenberg, \& Tomasello 2011, 328-331; Warneken, Lohse, Melis, \& Tomasello 2011, 267273). Opierając się na tego typu badaniach empirycznych i wychodząc z naturalistycznych założeń, że moralne zachowanie da się opisać i wyprowadzić z kategorii czysto biologicznych, transhumaniści proponują, by dokonywać interwencji genetycznych w celu udoskonalenia wrodzonych zdolności człowieka, na przykład odpowiedzialnych za samokontrolę. Tradycyjne reformy edukacji wydają się skazane na niepowodzenie, gdy uznamy, że główna przyczyna problemów w nauce i w życiu wynika z genów, a nie z systemu szkolnictwa (Levitt \& Dubner 2011, 156-171) ${ }^{6}$. Trudno więc się dziwić propozycji transhumanistów, którzy uważają więc udoskonalanie genetyczne za najskuteczniejszą metodę zapewnienia dzieciom lepszego startu w życiu. Biorąc pod uwagę silne uwarunkowanie genetyczne człowieka, twierdzą oni, że rodzice mają obowiązek moralny, by zapewnić potomstwu odpowiednie wyposażenie genetyczne, tak samo, jak mają obowiązek zagwarantować mu jak najlepsze warunki rozwoju (Savulescu 2001, 415; Savulescu \& Kahane 2009, 274-290; Kamm 2013, 253-290).

Nim jednak zaczniemy projektować dzieci zamiast je wychowywać, należy zastanowić się nad przedstawioną wyżej interpretacją wspomnianych badań. Zaobserwowanie korelacji pewnych zjawisk czy cech nie jest równoznaczne $\mathrm{z}$ udowodnieniem przyczyny ich występowania, co pokazuje rewizja wyników Marshmallow Test, dokonana przez grupę naukowców z uniwersytetu Rochester w 2012 roku (Kidd, Palmeri, Aslin 2012, 109-114). Za pomocą wprowadzenia nowych czynników do eksperymentu, naukowcy wykazali, że strategie dzieci w dokonywaniu wyboru pomiędzy natychmiastową nagrodą a nagrodą odłożoną $\mathrm{w}$ czasie nie zależą jedynie od czynników wrodzonych, ale w dużej mierze od czynników środowiskowych. Wykazano, że dzieci, które zostały poddane podobnym wyborom wcześniej, w sytuacjach, w których nie dotrzymano obietnicy

6 Ekonomiści analizują amerykański program reformy szkolnictwa, zatytułowany „No Child Left Behind” dostępny na stronie amerykańskiego Departamentu Edukacji: http://www2.ed.gov/nclb/landing.jhtml 
o gratyfikacji, bardziej były skłonne nie ufać eksperymentatorom w kolejnych wariantach testu i sięgały po nagrodę od razu. Innymi słowy, ich reakcja była racjonalną strategią opartą na dotychczasowym doświadczeniu. Z badań wyprowadzono wniosek, że dzieci pochodzące $\mathrm{z}$ mniej stabilnych rodzin, w których obietnice nie są dotrzymywane, a nagrody przypadają szybszym czy silniejszym, będą wykazywały mniej samokontroli, co może mieć również długofalowe skutki w kształtowaniu ich drogi życiowej. Ich strategie osiągania sukcesu nie są tylko wynikiem wrodzonych zdolności, ale raczej wynikiem kształtowania owych zdolności przez doświadczenie. Biorąc to pod uwagę, można nadal bronić idei biomedycznego ulepszania (promocji genów, ułatwiających zdobywanie cnót moralnych), twierdząc, że jest ono warunkiem koniecznym, ale niewystarczającym, by uczynić kogoś lepszym moralnie (Walker 2009, 35). Dla wykazania istotnej jakościowej różnicy pomiędzy wychowaniem a biomedycznym doskonaleniem samo kwestionowanie interpretacji powyższych badań empirycznych nie wystarczy. Nie chodzi tu bowiem o odrzucenie czynników genetycznych na rzecz czynników środowiskowych $\mathrm{w}$ procesie kształtowania człowieka. Należy się zgodzić, że zarówno czynniki genetyczne, jak i środowiskowe mają wpływ na naszą osobowość. Sedno zarzutu przeciwko moralnemu ulepszaniu biomedycznemu nie tkwi $\mathrm{w}$ zakwestionowaniu tego uwarunkowania, ale raczej $\mathrm{w}$ innym rozumieniu moralności, której nie da się ani utożsamić $z$ tym uwarunkowaniem, ani też $\mathrm{z}$ niego wyprowadzić. To inne rozumienie moralności zakłada, że jest ona nie tyle sferą doświadczenia, co raczej sferą działania (praxis), w której kluczową rolę odgrywa wola osoby.

Zwolennicy udoskonalania biomedycznego twierdzą, że różnica pomiędzy wychowaniem a genetycznym ulepszaniem jest jedynie różnicą stopnia, gdyż proces wychowawczy w nikłym stopniu uwzględnia wolę dziecka i w znacznym stopniu jest nieodwracalny w skutkach. Być może rzeczywiści, czysto mechaniczne „tresowanie” dziecka, wykorzystujące przewagę fizyczną czy psychiczną rodziców w celu kontrolowania jego rozwoju, nie respektuje woli dziecka podobnie, jak nie czyni tego prenatalna ingerencja w jego genotyp. W obu przypadkach dziecko (przyszłe lub obecne) jest jedynie przedmiotem określonych operacji, mających określony cel (najczęściej celem tym jest maksymalizacja preferencji rodziców ukryta pod pozorem realizacji domniemanego dobra dziecka).

Wychowanie można jednak rozumieć inaczej, jeśli zamiast na obserwowalnych skutkach tego procesu skoncentrujemy się raczej na zrozumieniu samego procesu i kluczowej dla niego relacji pomiędzy wychowawcą a wychowankiem (por. Zizek, Garz, \& Nowak 2015). Jeśli relację tę rozumiemy jako relację podmiot-przedmiot, gdzie wychowawca tworzy swego wychowanka niczym artysta dzieło, to wówczas istotnie nie będzie miało znaczenia, jakich używa do tego środków (prenatalnych uwarunkowań czy postnatalnych uwarunkowań, środków psychotropowych czy pasa) (Por. 
Sandel 2014, 47-60; odmiennie: Kamm 2013, 328-340). Można też rozumieć tę relację $\mathrm{w}$ kategoriach podmiotowych, akcentując aktywny udział dziecka w procesie wychowawczym (Por. Habermas 2003, 23-81).

Wyobraźmy sobie dziecko, które znęca się nad młodszymi dziećmi. Jeśli to dziecko nie jest niezrównoważone psychicznie (transhumaniści mówią o ulepszaniu osobników zdrowych), większość osób zgodzi się, że zastosowanie leczenia farmakologicznego jest w tym przypadku krokiem ostatecznym. Pierwszeństwo przypisujemy $\mathrm{z}$ reguły metodom wychowawczym, polegającym na tym, że rodzice lub opiekunowie próbują wytłumaczyć dziecku, dlaczego jego zachowanie jest złe; starają się zrozumieć, jakie są przyczyny tego zachowania; wreszcie podejmują wysiłek nauczenia dziecka, jak należy się zachowywać wobec innych, w tym słabszych, stosując odpowiednie przykłady. Pierwszeństwo owych metod wychowawczych nad interwencją medyczną wynika $\mathrm{z}$ określonego rozumienia charakteru moralnego człowieka, którego kształtowanie wymaga refleksyjnego zaangażowania danej osoby. Zaangażowanie dziecka w proces wychowawczy nie polega na realizacji pragnień dziecka, ale na rozwijaniu $w$ dziecku zdolności autorefleksji, by potrafiło ustosunkować się do swych pragnień, do tego, co robi i kim jest. Rozwinę tę myśl, w kolejnych punktach.

\subsection{Ordo amoris i habituacja}

Emocje i uczucia nie są dobre ani złe same w sobie; ocenie moralnej podlega raczej to jak się do nich sami ustosunkowujemy, co z nimi robimy i według jakich emocji czy uczuć działamy. Człowiek o stłumionej za pomocą środków biomedycznych agresywności nie wyrządzi co prawda krzywdy niewinnej osobie, ale również nie będzie w stanie odeprzeć ataku w sytuacji zagrożenia. Ponadto, emocje czy uczucia, których doznajemy są często spowodowane różnymi przeżyciami. Gdy dziecko wykazuje agresję, może to być symptomem poważnych problemów i wskazywać na przykład na chęć odreagowania doznanej krzywdy, potrzebę zwrócenia na siebie uwagi, poszukiwanie akceptacji czy frustrację wynikającą z braku miłości. Stłumienie tych symptomów albo niemożliwość ich ujawnienia spowoduje, że nie będziemy w stanie odkryć tych problemów i ich rozwiązać. Na gruncie wielu etyk perfekcjonistycznych, zwłaszcza w tradycji judeochrześcijańskiej, podkreśla się, że samodoskonalenie czy wychowanie nie mają prowadzić do stłumienia uczuć czy emocji, ale raczej do wewnętrznej przemiany, w której owe emocje i uczucia zostaną odpowiednio uporządkowane i ukierunkowane.

Św. Augustyn określił cnotę, za sprawą której dobrze żyjemy jako porządek w miłowaniu (ordo amoris) (Augustyn 2002, XV[XXII], 583). Kontynuując tę myśl, rozwijaną także przez Pascala, Max Scheler postawił tezę, że istnieje $\mathrm{w}$ ludzkim umyśle obiektywnie prawidłowy porządek poruszeń miłości i nienawiści, który stanowi jądro człowieka jako istoty 
duchowej (Scheler 1999, 123, 158). Mowa tu o aksjologicznej strukturze człowieka (Stróżewski 1999, 21-46), którą można określić też mianem etosu, czyli reguł preferencji wartości, określających nasz pogląd na świat i nasz sposób uczestnictwa w nim. Struktura ta jest w koncepcji Schelera radykalnie indywidualna, hierarchiczna, złożona, dynamiczna, dialektyczna, zarówno aktualna jak i potencjalna, teleologiczna, może być zarówno harmonijna, jak i zaburzona (Stróżewski 1999). Tak rozumianej struktury aksjologicznej nie da się zaprojektować genetycznie $\mathrm{z}$ dwóch powodów. Po pierwsze, wymagałoby to wszechwiedzy (pełnej wiedzy na temat tego, co będzie dobre dla danego człowieka i jak będzie wyglądało jego życie). Po drugie, nie jest ona tożsama ze strukturą biologiczną człowieka, gdyż jest ona efektem umiejętności zdystansowania się do niej i jej świadomego kształtowania w wyniku takich procesów jak wychowanie czy samodoskonalenie. Etos nie jest czymś danym człowiekowi, ale raczej zadanym, co ściśle wiąże się z ideą samorealizacji człowieka ( $\mathrm{z}$ autentycznością bycia sobą). Jak zauważa Władysław Stróżewski, „Człowiek-twórca jest przede wszystkim twórcą samego siebie" (Stróżewski 1999, 39), a jego struktura aksjologiczna tworzy się w ciągu całego życia.

Nie trzeba przyjmować założeń transcendentalnych, by bronić stanowiska, że moralności nie da się zredukować do kategorii biologicznych ani też na poziomie biologicznym kształtować. Nawiązując do Arystotelesa, John McDowell argumentuje, że cnoty moralne nabywamy przede wszystkim przez habituację, do której sprowadza się edukacja moralna, różniąca się od modyfikacji genetycznych nie tylko poprzez uświadomienie tego procesu:

Edukacja moralna nie jest zwykłym przekierowaniem z zastosowaniem rozumu czyichś naturalnych impulsów, gdzie jedyną różnicą jest to, że człowiek staje się samoświadomy operacji na owych impulsach. W stosowaniu logosu, moralna edukacja umożliwia cofnięcie się względem własnych impulsów motywujących, których jest się przedmiotem, i zakwestionowanie ich racjonalnego uwierzytelnienia. Tak też, efektem jest rodzaj zdystansowania się podmiotu względem praktycznych skłonności, które są częścią tego, co moglibyśmy nazwać jego pierwszą naturą (McDowell 2002, 188).

Zwolennicy transhumanizmu, którzy głoszą możliwość moralnego ulepszania natury człowieka za pomocą ingerencji biomedycznych zdają się wychodzić z założeń redukcjonistycznego naturalizmu, który próbuje wyjaśnić moralność w kategoriach uposażenia biologicznego i z tych kategorii wywieść. Jak trafnie zauważa Robert Piłat:

Najkrócej mówiąc, zwolennicy etycznego naturalizmu mówią rzeczy słuszne, ale nie na temat. Normy moralne mają charakter bezwzględny; nie polegają na statystycznym prawdopodobieństwie wyboru strategii współpracy. Habituacja nie jest normą, nawet jeśli jej wpływ jest tak mocny, że zawsze działa. 
Normatywność moralna wymaga silnej relacji, która wiąże bycie odpowiednim podmiotem z podleganiem odpowiednim normom (Piłat 2013, 177).

\subsection{Problem wolnej woli}

W przytoczonym wyżej fragmencie Mowy o godności człowieka, Pico della Mirandola wskazuje na istotną dla tych rozważań różnicę pomiędzy ludźmi a zwierzętami. Zwierzęta żyją w sposób czysto naturalny, zgodnie z prawami ich biologicznie zdeterminowanej natury. Ludzie zaś nie są całkowicie zdeterminowani czynnikami naturalnymi, dzięki czemu mają możliwość rozwoju duchowego (przekraczania swojej natury biologicznej)—rodzą się z określonym potencjałem i wolnością, by ów potencjał zarówno rozwinąć, jak i zmarnować. Podobną do Pico della Mirandoli myśl wyraził John Milton w Raju utraconym, opisując człowieka jako stworzenie rozumne i obdarzone wolnością:

\section{Jam go uczynił}

Tak sprawiedliwym i tak prawym, aby

Mógł stać, choć wolę miał wolną, by upaść... (Milton 1974, 64).

Powyższy fragment z Raju utraconego został przytoczony przez Harrisa w jednej z jego polemik z Savulescu, w której ten pierwszy odrzucił możliwość ulepszania moralnego człowieka, argumentując, że podstawą moralności jest wolność, z której nie można zrezygnować nawet za cenę przetrwania gatunku (Harris 2011, 102-111). Savulescu próbował odeprzeć zarzut, argumentując, że interwencje biomedyczne nie unicestwiają wcale wolności, pozostawiając ulepszonemu osobnikowi sferę wolności wyboru, czy swoje lepsze wyposażenie genetyczne wykorzystać, czy nie (Persson \& Savulescu 2012a, 513). Jednakże wolność związana z godnością człowieka, o której piszą Pico della Mirandola i Milton, nie jest tożsama ze swobodą wyboru preferencji, ani też ze swobodą działania. Wyższe gatunki zwierząt są również wolne w tym sensie, że mają swobodę wyboru pomiędzy różnymi preferencjami oraz swobodę działania zgodnie z tym wyborem. W normalnych warunkach słynny osiołek Buridana nie umarłby $\mathrm{z}$ pragnienia i głodu, gdyby umieszczono go w równej odległości pomiędzy sianem i wodą; nawet równie głodny, co spragniony osiołek dokona wyboru, czy najpierw zaspokoić pragnienie, czy głód. Z kolei człowiek, który znajduje się w sytuacji uniemożliwiającej mu realizację własnych preferencji (np. w niewoli, która ogranicza mu swobodne poruszanie się), będzie wciąż istotą wolną w znaczeniu moralnym, o którym tu mowa. Wolność tę należy bowiem rozumieć jako szczególną zdolność do kierowania własnym życiem, zgodnie z własnym rozeznaniem tego, co dobre i jednocześnie jako zdolność do przyjęcia pełnej odpowiedzialności za niepowodzenie w tym przedsięwzięciu.

Jeślibym sama $\mathrm{z}$ pełnym rozeznaniem doszła do wniosku, że najskuteczniejszym sposobem na opanowanie mego strachu jest wzięcie 
odpowiednich lekarstw, dzięki którym będę zdolna do podjęcia odważnej decyzji, jakiej wymaga ode mnie sytuacja i mój etos, to wówczas owa stymulacja farmakologiczna nie podważyłaby moralnego aspektu mego działania mimo, że nie jest ono wynikiem habituacji (przykład za: Korsgaard 1989, 123). Zachowana byłaby integralność moralna mojej osoby, co można bardziej precyzyjnie wyjaśnić odnosząc się do analitycznego rozróżnienia dwóch poziomów woli Harry'ego Frankfurta (Frankfurt 1997, 21-39). Brak spójności między różnymi poziomami pragnień pokazuje przykład narkomana, który pragnie skończyć ze swym nałogiem, ale nie może, gdyż jego chęć rzucenia nałogu (pragnienie drugiego rzędu) wchodzi w konflikt ze zbyt silnym uwarunkowaniem fizjologicznym jego chęci zażycia narkotyku (pragnieniem pierwszego rzędu). Zdaniem Frankfurta owa osoba nie jest w pełni autonomiczna, gdyż pozostaje wyalienowana ze swych pragnień. Dzięki pomocy farmakologicznej może on odzyskać autonomię, co dotyczyłoby również przykładu przezwyciężenia strachu za pomocą leków.

Jednakże biomedyczne doskonalenie człowieka, zakładające uwarunkowanie skłonności pierwszego rzędu, może również prowadzić do alienacji woli, jeśli będzie ją poprzedzać. Gdybyśmy zostali uwarunkowani genetycznie do nieodczuwania strachu, nie znaczyłoby to wcale, że jesteśmy wyposażeni w cnotę odwagi, gdyż brak odczuwanego strachu nie wynikałby z naszego pragnienia odwagi. Moglibyśmy wręcz cierpieć, niczym Wagnerowski Zygfryd, z tego powodu, że nie możemy odczuwać lęku. Genetyczne uwarunkowanie do altruistycznych skłonności prowadzić będzie do alienacji woli, jeśli nie będzie spójne z naszym pragnieniem dobra innych. Założenie, że określone skłonności biologiczne zwiększą prawdopodobieństwo spójnych z nimi sądów i działań moralnych (Douglas 2008, 229) całkowicie rozmija się z ideą wolnej woli, dzięki której sądy i działania moralne mają być osiągnięte. Wolność woli, o której tu mowa to wolność pragnienia tego, czego chce się pragnać (Frankfurt 1997, 38). A zatem nie tylko niezgodność pomiędzy pragnieniami pierwszego i drugiego rzędu powoduje poczucie braku tak rozumianej wolności, ale również świadomość, „iż ich zbieżność nie jest własnym dziełem”, jak pisze (Frankfurt 1997, 33).

Jeżeli przyjmiemy, że psychika człowieka jest tak skonstruowana, że zawsze będzie on dążył do integracji swych pragnień, to $\mathrm{w}$ kontekście moralnym będzie to raczej oznaczało dostosowanie pragnień pierwszego rzędu do pragnień drugiego rzędu, a nie na odwrót. Ordo amoris nie jest odwzorowaniem hierarchii naszych naturalnych pragnień według kryterium ich intensywności, ale raczej uporządkowaniem naturalnych pragnień zgodnie $\mathrm{z}$ ideą dobra. Pojawia się tu pytanie, czy ingerencje genetyczne przeprowadzane $\mathrm{w}$ okresie prenatalnym $\mathrm{w}$ celu udoskonalenia moralnego przyszłych pokoleń zakładają określoną, wspólną dla wszystkich ideę dobra, 


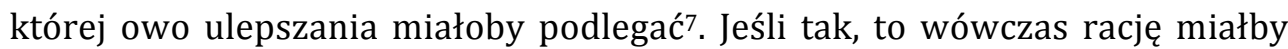
C.S. Lewis, że „tzw. "panowanie człowieka nad naturą« okazuje się panowaniem jednych ludzi nad innymi" (Lewis 2013, 69) ${ }^{8}$.

\section{Natura człowieka}

C. S. Lewis wskazuje na jeszcze jeden interesujący paradoks idei transhumanistów, polegającej na wzięciu ewolucji w swoje ręce, by poszerzyć zakres kontroli ludzkiej nad naturą:

Podbój natury przez człowieka okazuje się w chwili ostatecznego spełnienia podbojem człowieka przez naturę (Lewis 2013, 80; por. Habermas 2003, 56).

Aby lepiej zrozumieć ten paradoks, warto zwrócić uwagę na problematyczność pojęcia „natura człowieka”.

\subsection{Pytanie o osobowość i naturę człowieka}

Natura zwierząt jest całkowicie zdeterminowana czynnikami naturalnymi, dzięki czemu można zdefiniować, czym są określone zwierzęta odnosząc się do ich cech biologicznych. Definicja ich natury pozwala zaś odpowiedzieć na pytanie, co potrzebne jest zwierzętom określonego rodzaju do tego, by było im dobrze w tej odmianie życia, jakie wiodą. Z ludźmi jest jednak inaczej. Jak zauważa Hanna Arendt, naturalne warunki naszej egzystencji „nigdy nie »wyjaśnią«, czym jesteśmy ani nie odpowiedzą na pytanie, kim jesteśmy, z tego prostego powodu, że nigdy nie warunkują nas w sposób absolutny" (Arendt 2000,16). Warto tu odróżnić dwa oddzielne pytania, „Kim jestem?” i „Czym jestem?”, które Arendt znajduje u św. Augustyna (Augustyn 1994, X, 6, s. 215 ; tenże, $X, 17$, s. 227 ; por. Arendt 2000 , s. 15 , przypis 2). Na pierwsze pytanie, które dotyczy tożsamości człowieka, każdy odpowiada sobie sam własnym życiem. Jest to więc pytanie o osobę.

Drugie pytanie: „Czym jestem”, za którym podąża zaraz pytanie „Cóż mam uczynić?”, jest pytaniem o ludzką naturę (Augustyn 1994, X, 17, s. 227). Jest to pytanie teleologiczne, jak zauważa Arendt, które dotyczy ustalenia sensu człowieczeństwa. W pytaniu tym człowiek sam dla siebie staje się nierozwiązywalnym problemem, gdyż wymaga ono perspektywy zewnętrznej względem człowieka9 ${ }^{9}$ Można mieć uzasadnione wątpliwości, co do tego, czy

\footnotetext{
7 Sam Savulescu przyznaje, że zdefiniowanie tego, co dobre dla potomstwa jest najtrudniejszym zadaniem i najbardziej kontrowersyjnym, ale mimo wszystko uważa je za wykonalne (Savulescu 2001, 419).

8 Podobnie pisał Hans Jonas (por. Habermas 2003, 56).

${ }^{9}$ Augustyn kierował to pytanie do Boga-Stwórcy: "Przed oczyma Twymi stałem się dla siebie problemem i na tym właśnie polega moja choroba" (Augustyn 1994, X, 33, s. 242), por. Arendt 2000,15 , przypis 2 . Na temat pojęcia osoby i człowieczeństwa patrz także: Spaemann 2001.
} 
perspektywa stwórcy dostępna jest rodzicom czy też jakiejkolwiek grupie naukowców bądź filozofów. Przyjmując zaś, jak czynią to redukcjonistyczni naturaliści, że samowiedza gatunkowa jest nam dostępna, gdyż da się ją wyprowadzić $\mathrm{z}$ kategorii biologicznych warunkujących naszą naturę, popadniemy $\mathrm{w}$ przytoczony wyżej paradoks Lewisa, dążąc do zmiany tej samowiedzy za pomocą ingerencji w biologiczną strukturę gatunku.

\subsection{Człowiek jako istota moralna: autonomia i godność człowieka}

Można zadać pytanie, dlaczego przypadkowy zestaw skłonności, będący wynikiem loterii genetycznej miałby bardziej sprzyjać autonomii osoby niż zestaw genów, jaki byśmy otrzymali od planisty, ingerującego w nasz rozród (por. Habermas 2003, 23-81). Habermas próbuje odpowiedzieć na to pytanie, wskazując na różnicę między tworzeniem a narodzeniem, przywołując przy tym pochodzące od Arendt pojęcie „narodzin” (natality) (Habermas 2003, 6668; Arendt 2000, 13) ${ }^{10}$. Dla Arendt, narodzenie jako sposób znalezienia się na świecie, jest najważniejszym aspektem kondycji ludzkiej, stanowiącym podstawę teorii działania, zgodnie z którą człowiek jest sprawcą, który daje początek swym czynom. Pojawia się $\mathrm{w}$ tym kontekście rozumienie wolnej woli, pochodzące od św. Augustyna, zgodnie z którym wolną wolę definiuje się jako „zdolność dawania początku rzeczom i zdarzeniom” (Arendt 2002, 223). W przyrodzie nie istnieją narodziny i śmieć w naszym rozumieniu, jak zauważa Arendt, świat przyrody jest powtarzalny Arendt 2000, 107-108). Narodziny i śmierć istot ludzkich nie są dla nas tylko zwykłymi zdarzeniami naturalnymi, gdyż dotyczą unikalnych i niepowtarzalnych jednostek. Ludzie posiadają nie tylko życie $\mathrm{w}$ sensie biologicznym (zoe), ale także życie w rozumieniu społeczno-historycznym (bios), dzięki czemu możemy o nich powiedzieć, że mają swoją biografię. Przeżywanie własnej wolności w życiu jest ściśle związane $\mathrm{z}$ jej odniesieniem do czegoś, co nie podlega rozporządzeniu woli innych ludzi (Habermas 2003, 66). Jeśli więc zamiast być narodzonym, człowiek byłby tworzonym (miejsce warunkowania naszej biologicznej struktury przejąłby całkowicie człowiek), jego autonomia byłaby zagrożona.

Kant uczynił autonomię centralnym dla swojej filozofii moralności. W jego rozumieniu, pojęcie to nie sprowadza się do samej niezależności czy swobody wyboru, ale jest raczej rozumiane jako racjonalna zdolność do podporządkowania swojej woli uniwersalnemu prawu moralnemu (Kant 1981, 78-79). Tak rozumiana autonomia jest „podstawą godności natury ludzkiej i każdej natury rozumnej" (Kant 1981, 72). Kantowskie rozumienie

\footnotetext{
10 Angielskie słowo „natality“ jest neologizmem nawiązującym do słowa "mortality” (śmiertelność), za pomocą którego filozofka opisuje szczególność ludzkiej kondycji. Można by je zatem tłumaczyć jako „narodzeniowość” bądź „natalność”, ale żaden z tych neologizmów nie zadomowił się $\mathrm{w}$ polskiej literaturze, więc pozostawiam $\mathrm{w}$ tekście terminologię przyjmowaną przez tłumaczy.
} 
godności człowieka zakłada, że ma on wartość samą w sobie i jest zawsze celem, a nie tylko środkiem działania:

Wszystko ma jakąś cenę albo godność. To, co ma cenę można zastąpić także przez coś innego, jako jego równoważnik, co zaś wszelką cenę przewyższa, a więc nie dopuszcza żadnego równoważnika, posiada godność.

To, co odnosi się do powszechnych ludzkich skłonności i potrzeb, ma cenę rynkową; to, co bez względu na jakąś potrzebę odpowiada jakiemuś smakowi, tj. upodobaniu ..., posiada cenę uczuciową; to zaś, co stanowi warunek, pod którym jedynie coś może być celem samym w sobie, ma nie tylko względną wartość, tj. cenę, lecz wartość wewnętrzną, tj. godność.

Moralność jest warunkiem, od którego jedynie zależy to, że istota rozumna może być celem samym dla siebie, ponieważ tylko dzięki niej można być prawodawczym członkiem w państwie celów. A więc jedynie moralność i ludzkość, o ile jest zdolna do moralności, są tym, co posiada godność (Kant 1981, 70-71).

Wewnętrzna wartość osoby jest niewymierna, unikalna i niekumulatywna: nie da się jej zmierzyć według jakiejś wspólnej wszystkim ludziom miary, porównać z wartością innej osoby, zastąpić, ani zsumować (Kołakowski 2014, 119). Choć przyrodzonej godności nie można nikogo pozbawić, można jej nie uszanować, pozbawiając osobę możliwości wrażenia swojej godności (przeżywania swojej autonomii w pełni) (Spaemann 2006, 151).

Rozporządzanie właściwościami genetycznymi przyszłych ludzi w celu moralnego ich udoskonalenia może się wydawać wtargnięciem w ich sferę autonomii i naruszeniem ich godności w rozumieniu kantowskim, na co wskazywał Habermas (Habermas 2003, 23-81). Polemizujący z Habermasem transhumaniści odrzucają jego tezę wychodząc $\mathrm{z}$ innych założeń na temat tego, czym jest człowiek i jak należy rozumieć wolność (Pugh 2014 , 2). Aby lepiej ten problem zrozumieć warto tu przytoczyć za Kołakowskim i Korsgaard rozróżnienie pomiędzy dwoma odmiennymi perspektywami filozoficznymi, $\mathrm{z}$ których inaczej postrzega się naturę człowieka; w uproszczeniu można je określić mianem kantowskiej (racjonalistycznej) i darwinowskiej (naturalistycznej) tradycji myślenia (Kołakowski 2014, 118; Korsgaard 1989, 120)11. Zgodnie z tym drugim podejściem, skłonności moralne są adaptacjami ewolucyjnymi, które można zaobserwować w uboższej wersji także u wyższych gatunków zwierząt; mają one charakter funkcjonalny i służą realizacji potrzeb gatunkowych; gatunek jest więc „właściwym podmiotem i przedmiotem zachowań, które można oceniać w kategoriach moralnych" (Kołakowski 2014, 118). W związku z tymi założeniami, szczególny status gatunku ludzkiego obecny w doktrynie

11 Interesującą analizę krytyczną stanowiska racjonalistycznego Korsgaard oraz stanowisk naturalistycznych można znaleźć w: Piłat 2013; autor podkreśla, że oba typy stanowisk są niekompletne. 
godności człowieka wydaje się nieuzasadniony i może być interpretowany jako wyraz „szowinizmu gatunkowego”, jak twierdzi Peter Singer (Singer 2007, 65 i n.). Ujęcie kantowskie przyjmuje zaś, że moralność nie należy do sfery skłonności i użyteczności, ale do sfery rozumu i wolnej woli, które wyróżniają ludzi spośród innych istot żywych; „osoba ludzka jest zarówno podmiotem woli, jak i ostatecznym przedmiotem wszelkiej intencji moralnej" (Singer 2007, 65), nie ma charakteru funkcjonalnego, ale ma wartość samą w sobie. Godność ludzka w ujęciu kantowskim jest ideą regulatywną, bez której nie sposób zrozumieć normatywnego sensu człowieczeństwa.

Julian Huxley, któremu przypisuje się ukucie terminu „transhumanizm”, stawia pytanie: „po co jesteśmy?” (cyt. za: Bashford 2013, 161). W zależności od tego, czy wyjdziemy z założeń kantowskich, czy z założeń darwinowskich, całkowicie odmiennie zinterpretujemy to pytanie i tym samym dojdziemy do odmiennych wniosków na temat ulepszania moralnego człowieka.

\section{Uwagi końcowe: między utopią a dystopią}

Aldous Huxley zasłynął jako autor Nowego wspaniałego świata-dystopiiprzedstawiającej czarną wizję ingerencji w ewolucję, którą postulował jego starszy brat Julian Huxley. Obaj bracia byli wnukami słynnego biologa darwinisty Thomasa Henry'ego Huxleya. Tłumaczy to ich zainteresowania teorią ewolucji, choć obaj inaczej oceniali możliwości i zagrożenia, jakie rozwój biotechnologii może przynieść. Pisarz przedstawił w swej książce świat, który kieruje się ideą standaryzacji ludzkości, zaprowadzonej dzięki programowi sztucznego rozrodu i warunkowania $\mathrm{w}$ celu stworzenia uspołecznionych istot ludzkich (tj. takich, które polubiłyby swoje przeznaczenie społeczne). Opisana przez Huxleya cywilizacja, która „wybrała maszyny, medycynę i szczęśliwość" (Bashford 2013, 333) nie potrzebuje cnót moralnych $\mathrm{w}$ tradycyjnym znaczeniu, gdyż tylko społeczności niestabilne (to jest, nieuwarunkowane) potrzebują heroizmu, szlachetności, czy poświęcenia. Tradycyjne cnoty moralne zastąpione zostają środkami farmakologicznymi takimi, jak soma:

Soma ukoi gniew, pogodzi z wrogami, doda cierpliwości i wytrwałości. Dawniej można to było osiągnąć tylko wielkim wysiłkiem po latach trudnych ćwiczeń woli. Dziś połyka się dwie lub trzy półgramowe tabletki i załatwione. Dziś każdy obdarzony jest cnotami. Co najmniej połowę swej moralności nosi w fiolce. Chrześcijaństwo bez łez, oto czym jest soma (Bashford 2013, 337).

Użyteczność ludzkiego istnienia zostaje jednak zakwestionowana przez pragnienie wolności, ale nie wolności do szczęścia w ogóle, tylko do szczęścia na swój własny sposób (Huxley 2013, 130-131). Gdy jeden z bohaterów 
domaga się prawa do niedoskonałości i do bycia nieszczęśliwym (Huxley 2013, 340), domaga się innymi słowy wolności do upadku, o której pisał Milton i której wielu filozofów moralności przypisuje centralne znaczenie.

Choć zarówno utopia, jak i anty-utopia każdego z braci Huxley'ów jest przesadzona, w obu można zidentyfikować źródłowe intuicje dotyczące sporu o transhumanizm, na które próbowałam zwrócić uwagę w tym artykule. Odpowiedź na pytanie, czy ulepszać naturę moralną człowieka zależy od przyjętych założeń odnośnie tego, czym ta natura jest i czym powinna być. Innymi słowy, odpowiedź zależy od sensu, jaki nadamy idei człowieczeństwa.

\section{Literatura}

Agar, N. 2008. Liberal Eugenics: In Defence of Human Enhancement. Malden, MA: Blackwell.

Arendt, H. 2000. Kondycja ludzka. Tłum. A. Łagodzka. Warszawa: Aletheia.

Arendt, H. 2003. O rewolucji. Tłum. M. Godyń. Warszawa: Czytelnik.

Augustyn, św. 1994. Wyznania. Tłum. Z. Kubiak. Kraków: Znak.

Augustyn, św. 2002. Państwo Boże. Tłum. ks. W. Kubicki. Kęty: Wydawnictwo Antyk.

Bashford, A. 2013. "Julian Huxley's transhumanism". W M. Turda (ed.), Crafting Humans. From Genesis to Eugenics and Beyond. Göttingen: Vandenhoeck \& Ruprecht: 153-167.

Birnbacher, D. 2008. "Posthumanity, Transhumanism and Human Nature". W: G. Gordijn \& R. Chadwick (eds), Medical Enhancement And Posthumanity. Berlin: Springer: 95-106.

Bostrom, N. 2008. "Why I Want To Be a Posthuman When I Grow Up". W G. Gordijn \& R. Chadwick (eds.), Medical Enhancement and Posthumanity. Berlin: Springer. 107-137.

Burckhardt, J. 1991. Kultura Odrodzenia we Włoszech. Tłum. M. Kreczkowska. Warszawa: PIW.

Collins, F. C. 2006. The Language of God. A Scientist Presents Evidence for Belief. New York: Free Press.

Douglas, T. 2008. "Moral Enhancement". Journal of Applied Philosophy 25(3): 228-245.

Drwięga, M. 2008. „W poszukiwaniu doskonałości. Natura ludzka i etyka w dobie inżynierii genetycznej". Diametros 16: 80-91.

Frankfurt, H.G. 1997. „Wolność woli i pojęcie osoby”. W J. Hołówka (red. naukowa), Filozofia moralności. Postanowienie $i$ odpowiedzialność moralna. Tłum. J. Nowotniak. Warszawa: Aletheia: 21-39.

Fukuyama, F. 2014. Koniec człowieka. Konsekwencje rewolucji biotechnologicznej. Tłum. B. Pietrzyk. Kraków: Znak. 
Habermas, J. 2003. Przyszłość natury ludzkiej. Tłum. M. Łukasiewicz. Warszawa: Wydawnictwo Naukowe SCHOLAR.

Hamann, K., Warneken, F., Greenberg, J., \& Tomasello, M. 2011. “Collaboration Encourages Equal Sharing in Children But Not Chimpanzees." Nature 476: 328-331.

Harris, J. 2007. Enhancing Evolution. The Ethical Case for Making Better People. Princeton: Princeton University Press.

Harris, J. 2011. "Moral Enhancement and Freedom." Bioethics 25(2): 102-111.

Huxley, A. 2013. Nowy, wspaniały świat. Tłum. B. Baran. Warszawa: Muza.

Huxley, J. 1968. "Transhumanism". Journal of Humanistic Psychology 8(1): 7376.

Kamm, F. 2013. "What As And What Is Not Wrong with Enhancement. Evaluating Sandel's View." W idem, Bioethical Prescriptions: To Create, End, Choose, and Improve Lives. Oxford: Oxford University Press.

Kant, I. 1981. Uzasadnienie metafizyki moralności. Tłum. M Wartenberg. Warszawa: PIW.

Kant, I. 2001. Krytyka czystego rozumu. Tłum. R. Ingarden. Kęty: Wydawnictwo Antyk.

Kass, L. R. 1997. "The Wisdom of Repugnance." The New Republic 2(6): 17-26.

Kidd, C., Palmeri, H., \& Aslin, R. N. 2012. "Rational Snacking: Young Children's Decision-Making on the Marshmallow Task Is Moderated by Beliefs About Environmental Reliability." Cognition 126(2013): 109-114.

Kołakowski, L. 2014. Niepewność epoki demokracji. Kraków: Znak.

Korsgaard, Ch. M. 1989. "Personal Identity and the Unity of Agency: A Kantian Response to Parfit." Philosophy \& Public Affairs 18(2): 101-132.

Levitt, S. D. \& Dubner, J. 2011. Freakonomia. Świat od podszewki. Tłum. A. Sobolewska. Kraków: Znak.

Lewis, C.S. 2013. Koniec człowieczeństwa. Tłum. M. Sobolewska. Kraków: Esprit.

McDowell, J. 2002. „Two Sorts of Naturalism”. W: J. McDowell. Mind, Value, And Reality. Harvard University Press, Cambridge, Mass. - London: 167197.

Milton, C. 1974. Raj utracony. Tłum. M. Słomczyński. Kraków: Wydawnictwo Literackie.

Mischel, W., Shoda, Y., Rodriguez, M.L. 1989. "Delay of Gratification in Children." Science 244: 933-938.

Persson, I., Savulescu, J. 2008. "The Perils of Cognitive Enhancement and the Urgent Imperative to Enhance the Moral Character of Humanity". Journal of Applied Philosophy 25(3): 166-167.

Persson, I., Savulescu, J. 2012a. Unfit for the Future: The Need for Moral Enhancement, Oxford: Oxford University Press.

Persson, I., Savulescu, J. 2012b. "Moral Enhancement, Freedom And God Machine." The Monist 95(3): 399-421. 
Piłat, R. 2013. „Refleksja i kompetencja moralna”. W idem, Powinność i samowiedza. Warszawa: Wydawnictwo UKSW: 169-188.

Pugh, J. 2014. "Autonomy, Natality And Freedom: A Liberal Re-Examination of Habermas in the Enhancement Debate." Bioethics 29(3): 145-152.

Sandel, M. 2014. Przeciwko udoskonalaniu człowieka. Etyka $w$ czasach inżynierii genetycznej. Tłum. O. Siara. Warszawa: Kurhaus Publishing.

Savulescu, J. 2001. "Procreative Beneficence: Why Should We Select the Best Children?." Bioethics 15(5/6): 413-426.

Savulescu, J. \& Kahane, G. 2009. "The Moral Obligation to Create Children with the Best Chance of the Best Life". Bioethics 23(5): 274-290.

Savulescu, J., Sandberg A., \& Kahane, G. 2011. „Well-Being and Enhancement”. W J.Savulescu, R. Meulen, \& G. Kahane (eds.), Enhancing Human Capacities. New York: Wiley-Blackwell: 48-88.

Scheler, M. 1999. „Ordo amoris w znaczeniu opisowym i normatywnym”. Tłum. W. Czapliński. Kwartalnik Filozoficzny XXVI (4): 123-158.

Shoda, Y., Mischel, W., \& Peake, P. K. 1990. „Predicting Adolescent Cognitive And Self-Regulatory Competencies from Preschool Delay of Gratification: Identifying Diagnostic Conditions." Developmental Psychology 26(6): 987-986.

Singer, P. 2007. Etyka praktyczna. Tłum. A. Sagan. Warszawa: Książka i Wiedza.

Soniewicka, M. 2015. „Biologiczne podstawy moralności w kontekście genetycznego ulepszania człowieka". W J. Stelmach, B. Brożek, \& K. Eliasz (red. naukowa), Naturalizacja prawa: interpretacje. Warszawa: Wolters Kluwer: 279-298.

Spaemann, R. 2001. Osoby. Tłum. J. Merecki. Warszawa: Oficyna Naukowa.

Spaemann, R. 2006. Granice. O etycznym wymiarze działania. Tłum. J. Merecki. Warszawa: Oficyna Naukowa.

Stróżewski, W. 1999. „Aksjologiczna struktura człowieka”. Kwartalnik Filozoficzny XXVI (4): 21-46.

Walker, W. 2009. „Enhancing Genetic Virtue: A Project for Twenty-First Century Humanity?." Politics and the Life Sciences 28(2): 27-47.

Warmbier, A. 2015. „Moral Perfection and the Demand for Human Enahncement". Ethics in Progress 6 (1): 23-37.

Warneken, F., Lohse, K., Melis, A., \& Tomasello, M. 2011. „Young Children Share the Spoils After Collaboration." Psychological Science 22: 267-273.

Zizek, B., Garz, D., \& Nowak, E. (eds.) 2015. Kohlberg Revisited. Rotterdam Boston - Taipei: Sense Publishers. 


\title{
Marta Soniewicka (Cracow)
}

\section{Transhumanism: Some Remarks on the Philosophical Sources of the Debate over the Idea of Biomedical Moral Enhancement}

\begin{abstract}
The paper addresses the problem of the philosophical sources of the debate over moral human enhancement held between transhumanists and bio-conservatives. The paper is aimed at showing that the opposing positions in the debate are grounded in different philosophical traditions, namely naturalistic (Darwinian) and rationalistic (Kantian), which define human nature differently. Morality and moral improvement are also differently understood in these different traditions, thus the assumptions rooted in them lead to different conclusions concerning the idea of human moral enhancement and its justification.
\end{abstract}

Keywords: Transhumanizm, natura człowieka, genetyka, naturalizm, bioetyka, transhumanism, human nature, genetics, naturalism, bioethics

Ethics in Progress (ISSN 2084-9257). Vol. 6 (2015). No. 1, pp. 38-55.

doi: 10.14746/eip.2015.1.5 